\title{
The Church in the Light of Learned Ignorance
}

\author{
THOMAS M. IZBICKI
}

The years between 1436 and 1442 were vital ones in the life and thought of Nicholas of Cusa, who entered that period as the leading conciliar theorist of his generation and emerged from it as a papal apologist, "the Hercules of the Eugenians," as well as one of the most original speculative thinkers of the Renaissance. $\mathrm{Cu}$ sanus's change of ecclesiological emphasis coincided with the eclipse of Cardinal Giuliano Cesarini, with whom he was closely associated, as leader of the Council of Basel, and the rise of Cardinal Louis d'Aleman, an ardent foe of Eugenius IV, to supplant him. This change of leadership itself coincided with the factional division of the assembly over the site of a council of union with the Greeks and a change in emphasis from open debate on issues of faith, unity, and reform to the attempt to declare conciliar supremacy a dogma. ${ }^{1}$ Cusanus's own change of allegiance cannot be divorced from his own self-interest; ${ }^{2}$

1. On the change in the council, see Giuseppe Alberigo, Chiesa conciliare: Identità $e$ significato del conciliarismo (Brescia: Paideia, 1979), pp. 256-340. On Cesarini's eclipse, see Gerald Christianson, Cesarini, the Conciliar Cardinal: The Basel Years, 1431-1438 (St. Ottilien: EOS, 1979), pp. 149-180.

2. See, most recently, Joachim W. Stieber, "The 'Hercules of the Eugenians' at the Crossroads: Nicholas of Cusa's Decision for the Pope and Against the Council in 1436/1437-Theological, Political and Social Aspects," in Nicholas of Cusa in Search 
nor can it be separated from the fortunes of Cesarini, to whom, together with Emperor Sigismund, he had dedicated De concordantia catholica, and whom he had supported in the climactic struggle over the location of a council of union. ${ }^{3}$ This transformation, however, cannot be divided from the contemporaneous changes occurring in Cusanus's internal life, which caused him to emphasize speculative rather than institutional themes in his later writings. Following a mystical experience on a ship returning from Constantinople, where he had been representing both Eugenius and the minority faction at Basel, Cusanus entered the middle phase of his literary life, during which he developed his idea of learned ignorance and his methodology of conjecture. 4

Reviewing these changes in Cusanus's life and thought, scholars have been inclined to emphasize discontinuity, especially between his speculative concepts and his previous ecclesiological and political themes. Also little attention is given Nicholas's papalist polemics, either because his major treatises put them in the shade or because they seem like puny siblings of De concordantia catholica..$^{5}$ A closer examination of them reveals, however, that they both reflect Cusanus's struggle to establish a new identity apart from the Council of Basel and an effort to fit his papalism into the larger frame of his speculative thought. Both of these developments coincided in Nicholas's letter to Rodrigo Sánchez de Arévalo (1442), which determined the nature of his later ecclesiology, as expressed in his sermons and his Reformatio generalis (c. 1459). This ecclesiology, however, could not free Cusanus

of God and Wisdom: Essays in Honor of Morimichi Watanabe, ed. Gerald Christianson and Izbicki (Leiden and New York: Brill, 1991), pp. 221-255.

3. See, respectively, Nicholas of Cusa, The Catholic Concordance, tr. Paul Sigmund (Cambridge: Cambridge University Press, 1991); H. Lawrence Bond, Christianson, and Izbicki, "Nicholas of Cusa: On Presidential Authority in a General Council," Church History 59 (1990): 19-34; Der Briefwechsel des Eneas Sylvius Piccolomini, ed. R. Wolkan, 1/1 (Vienna: Hölder, 1909), pp. 58-76, no. 24, at p. 65.

4. J. E. Biechler, "Nicholas of Cusa and the End of the Conciliar Movement: A Humanist Crisis of Identity," Church History 44 (1975): 5-21.

5. See, respectively, Pauline Moffitt Watts, Nicolaus Cusanus: A Fifteenth Century Vision of Man (Leiden: Brill, 1982) and the brief treatments of Cusanus's later ecclesiological works in Morimichi Watanabe, The Political Ideas of Nicholas of Cusa (Geneva: Droz, 1963), pp. 97-114; Paul E. Sigmund, Nicholas of Cusa and Medieval Political Thought (Cambridge, Mass.: Harvard University Press, 1963), pp. 261-280. 
from German suspicions that he had betrayed the Council of Basel and that, whatever his reforming efforts, he could not be trusted as papal legate or as bishop of Brixen. ${ }^{6}$

Cusanus's struggle to define himself as a papalist evolved in the context of his role as a papal representative in Germany between 1439 and 1444, where he attended several of the diets and other meetings which tried in vain to choose between the Council of Basel and its pope, Felix V, and Eugenius IV and his council at Ferrara, Florence, Siena, and, ultimately, Rome. The Germans attempted to maintain a stance variously described as "neutrality" or "eitherness" (utralitas), refusing to make a final decision for either party while negotiating with both. A common proposal for ending the "conciliar crisis" was a council, preferably at Constance, which would continue the Council of Basel as if it never had been divided and would choose between Eugenius and Felix. ${ }^{7}$ These German deliberations would fail to enforce such a policy and, ultimately, would be abandoned for recognition of Eugenius on terms favorable to the princes. 8

In 1439, however, Cusanus could not foresee these results; and he had to put on a bold face to confront conciliarists and neutralists alike. His earliest polemics, beginning with a letter to an imperial advisor, arguing in vain against the policy of neutrality adopted by Albrecht II, the brief-lived Hapsburg king of the Romans, emphasized a theme consistent with his earlier, more conciliar works, that of

6. Izbicki, "Auszüge aus Schriften des Nikolaus von Kues im Rahmen der Geschichte des Basler Konzils," Mitteilungen und Forschungsbeiträge der Cusanus-Gesellschaft 19 (1991): 117-135; Donald Sullivan, "Nicholas of Cusa as Reformer: The Papal Legation to the Germanies, 1451-1452," Mediaeval Studies 36 (1974): 382428; Erich Meuthen, "Die deutsche Legationsreise des Nikolaus von Kues 1451/52," Lebenslehren und Weltentwürfe im Übergang vom Mittelalter zur Neuzeit, ed. Hartmut Bookmann et al. (Gottingen: Vandenhoek \& Ruprecht, 1989), pp. 421-499; Watanabe, "Nicholas of Cusa and the Tyrolese Monasteries-Reform and Resistance," History of Political Thought 7 (1986): 53-72.

7. This proposal sometimes is described as a plan for a "third" council; see R. Bäumer, "Eugen IV und der Plan eines 'Dritten Konzils' zur Beilegung des Basler Schismas," Reformata Reformanda: Festgabe für Hubert Jedin, ed. Erwin Iserloh and Konrad Repgen (Munster: Aschendorff, 1965) 1:87-128.

8. Joachim Stieber, Pope Eugenius IV, the Council of Basel and the Secular and Ecclesiastical Authorities (Leiden: Brill, 1979). 
consent. The case for Eugenius and against both Felix and neutrality drew on both law and history; but Cusanus emphasized the need for Basel to prove, to justify its actions against a reigning pope, that the princes or the Church dispersed throughout the world had consented. ${ }^{9}$ The same argument would recur in 1441 in a polemical exchange with a Carthusian monastery concerning the nature and powers of a council. Nicholas argued that a valid council requires concords and the consent of the entire Church, including pope and cardinals. Basel, he said, was a seat of discord; but the Church was represented at Florence, where concord prevailed and the pope was present consenting to conciliar acts. ${ }^{10}$ Also in 1441 , in a letter to the archbishop of Trier, Cusanus made the first of several attempts to prove that Germany must give up neutrality and, without evasion, embrace Eugenius. ${ }^{11}$

How little the argument from consent mattered, even in the narrow public of ecclesiological debate, can be seen from Cusanus's dispute with Thomas Ebendorfer, the theological architect of neutrality, at the time of the Diet of Mainz (1441). Nicholas argued that papal consent was required to validate any conciliar enactment, even the decree Frequens of the Council of Constance, on which much of the argument against translation of the Basel assembly to Ferrara turned. The pope could be disobeyed only if his actions endangered the Church, a threat absent when Basel acted against a reigning Roman pontiff. ${ }^{12}$ This argument and others like it weighed little

9. Acta Cusana: Quellen zur Lebensgeschichte des Nikolaus von Kues 1/2, ed. Erich Meuthen and Hermann Hallauer (Hamburg: Meiner, 1983), pp. 268-273, no. 408. On Nicholas's ability to recycle his older ideas within the broader context of medieval "political languages," see Antony Black, "Political Languages in Later Medieval Europe," in The Church and Sovereignty c. 590-1918, ed. Diana Wood, Studies in Church History Subsidia 9 (Oxford: Blackwell, 1991), pp. 313-328. These languages, however, should be understood as sources employed within the broader language of arguments from reason and authority; see Juan de Torquemada, A Disputation on the Authority of Pope and Council, tr. Izbicki (Oxford: Blackfriars, 1988), pp. xvi-xvii.

10. Acta Cusana 1/2:305-13, no. 468.

11. Acta Cusana 1/2:313-20, no. 469. See also pp. 322-325, no. 473, and pp. 432-436, no. 527.

12. Acta Cusana 1/2:342-52, no. 481. On Ebendorfer's role, see Alphons Lhotsky, Thomas Ebendorfer (Stuttgart: Hiersemann, 1957), p. 36. 
with German theologians like Ebendorfer, Bartholomew of Maastrich, and Johann Wenck, the leading critic of Nicholas's speculative doctrines. ${ }^{13}$ Cusanus himself revealed his awareness of how vulnerable his conciliar past left him by arguing, in his contemporaneous Dialogus concludens errorem Amadeistarum, a first essay at a literary genre which would be used often in his later writings, the imaginary conversation. The interlocutors in this dialogue were a master, obviously Cusanus himself, and his disciple. The latter's request for an explanation of his teacher's change of ecclesiastical allegiance led to a remarkably benign interpretation, for a papalist, of both the Council of Constance and of the earliest sessions at Basel. Radicalization was the fault of latecomers; and their acts were invalid, since the pope had not consented to them. This argument was coupled with a lame contention that God would not let the reigning pope damage the Church and an insistence, almost in the teeth of that argument from Providence, that the pope had to act to build up the Church. ${ }^{14}$ This last emphasis would be taken up in the letter to Arévalo and Cusanus's other writings on the Church.

The discontent Cusanus must have felt at such lame arguments, so lacking in speculative content or originality, is apparent from his letter to Rodrigo Sánchez de Arévalo, ${ }^{15}$ written in 1442, when he expected that Castilian canonist, who was representing his king, Juan II, in Germany, to join him at the Diet of Frankfurt in defending Eugenius IV and his council against Basel, Felix V, and neutrality. This letter must be read, however, in the light of Cusanus's great speculative treatises De docta ignorantia and De coniecturis, the major works of the middle phase of his writing career, which had been

13. Acta Cusana 1/2:359-62, no. 484; pp. 325-326, no. 474; pp. 326-328, no. 475. See also Nicholas of Cusa's Debate with John Wenck, ed. and tr. Jasper Hopkins, 2d ed. (Minneapolis: Banning, 1981).

14. Erich Meuthen, "Nikolaus von Kues: Dialogus concludens Amadeistarum errorem ex gestis et doctrina concilii Basiliensis," Mitteilungen und Forschungsbeiträge der Cusanus Gesellschaft 8 (1970): 11-114. See also Acta Cusana 1/2:363, no. 488.

15. Richard H. Trame, Rodrigo Sánchez de Arévalo, 1404-1470 (Washington, D.C.: Catholic University of America Press, 1958), pp. 53-57; Juan Maria Laboa, Rodrigo Sánchez de Arévalo, alcalde de Sant'Angelo (Madrid: Publicaciones de la Fundación Universitaria Española, 1973), p. 45. 
completed in this same period. 16 Although the nominal topic of the letter was the present state of the Church, it also contains a more general theological statement, an expression of Cusanus's Christology and, in the light of this Christology, a contribution to the ongoing debate on the True Church (vera ecclesia). Cusanus would conclude, as shall be demonstrated below, that the True Church could not be seen by men; but its presence could be discerned through "sacred signs" where the faith of Peter in the Incarnate Lord was professed and the body of Christ was built up by Peter's successor, the "sacred prince," the pope. ${ }^{17}$ Only in this speculative context would Cusanus find a papalist idiom with which he could rest content.

The place of Christ at the heart of Cusanus's thought cannot be emphasized too strongly. The hypostatic union of Divinity and humanity in Jesus bridged the gap between "finite mind" and "Infinite Truth." 18 This emphasis was not limited to any one work. One need only mention that place of the Word as interlocutor in the irenic discussion of religious differences in De pace fidei, the central role of the icon in De visione Dei, or the winning score of 34 in De ludo globi, which equals the age of Jesus at the time of His Passion. ${ }^{19}$ The key exposition of Cusanus's Christology, however, at least for our purposes, can be found in De docta ignorantia 3. The first two books were concerned with a doctrine of creation which left the Creator

16. For the periodization of Cusanus's works, see F. Edward Cranz, "The Late Works of Nicholas of Cusa," in Nicholas of Cusa in Search of God and Wisdom, pp. 141160.

17. Quotations from Cusanus's letter to Rodrigo Sánchez de Arévalo are taken from the translation included as an appendix to this article.

18. H. Lawrence Bond, "Nicholas of Cusa and the Reconstruction of Theology," Medieval Christian Tradition: Essays in Honor of Ray C. Petry, ed. George H. Shriver (Durham, N.C.: Duke University Press, 1974), pp. 81-94; Rudolf Haubst, Die Christologie des Nikolaus von Kues (Freiburg i. B.: Herder, 1956); Haubst, "Der Leitgedanke der repraesentatio in der cusanischen Ekklesiologie," Mitteilungen und Forschungsbeiträge der Cusanus-Gesellschaft 9 (1971): 140-159.

19. Nicholas of Cusa, On Interreligious Harmony, ed. James E. Biechler and H. Lawrence Bond (Lewiston: Mellen, 1990); Nicholas of Cusa's De pace fidei and Cribratio Alkorani, tr. Jasper Hopkins (Minneapolis: Banning, 1990); Nicholas of Cusa's Dialectical Mysticism, tr. Jasper Hopkins, 2nd ed. (Minneapolis: Banning, 1988); Nicholas of Cusa, The Games of Spheres, tr. Pauline Moffitt Watts (New York: Abaris, 1986). 
unknowable by the faculties of the creatures, including a defense of Negative Theology, in which Truth "shines incomprehensibly within the darkness of our ignorance." 20 In Book 3, Nicholas set out to show the coincidence of the "absolutely Maximum" and the "contracted maximum" in Jesus. ${ }^{21}$ These opposites coincided in the hypostatic union of divine and human natures in Christ, a union transcending human knowledge, since "Absolute God" did not become confused with created matter. ${ }^{22}$ This union produced the maximum individual, of whom there only could be one; but He elevated human nature above the angels, becoming the "universal contracted being of each creature," "the Word [of God] in whom all things were created."23

In this light, Cusanus explicated the Incarnation, Passion, and Resurrection of Jesus as the means of salvation and as the fulfillment of the hypostatic union. ${ }^{24}$ The Saracens, that is, the Muslims, and the Jews were censured for affirming certain truths of the faith while denying others. Here we find a negative form of what appears as a positive argument in De pace fidei, the argument that other religions approach the truth without attaining it. ${ }^{25}$

Only in the last two chapters of De docta ignorantia did Cusanus address directly the ecclesiological dimensions of his subject. In chapter 11, Cusanus's emphasis fell upon faith as understanding's guide, with understanding, in turn, helping faith to increase. ${ }^{26}$ Faith, God's gift, revealed the treasures of wisdom and knowledge to the limited human intellect. ${ }^{27}$ Faith united the believer with Jesus, receiving from Him power over "nature and motion." The wondrous deeds of the saints were evidence of the power Jesus conferred on the

20. The Latin text of this work can be found in Nicholas of Cusa, Opera omnia 1 (Leipzig: Meiner, 1932). The English quotations are taken from Nicholas of Cusa on Learned Ignorance, tr. Jasper Hopkins (Minneapolis: Banning, 1981), pp. 49-124, esp. p. 85 .

21. On Learned Ignorance, p. 125.

22. On Learned Ignorance, pp. 128-130.

23. On Learned Ignorance, pp. 130-133.

24. On Learned Ignorance, pp. 135-142.

25. On Learned Ignorance, pp. 143-144. On Cusanus and Islam, see James E. Biechler, "Nicholas of Cusa and Mohammed: A Fifteenth Century Encounter," Dounside Review 101 (1983): 50-59.

26. On Learned Ignorance, p. 149.

27. On Learned Ignorance, pp. 149-151. 
believer. ${ }^{28}$ The Thomist tradition, represented in Cusanus's day by Juan de Torquemada, among others, distinguished between unformed faith, expressed in baptism, and formed faith, enlivened by charity, Augustine's mark of membership in the True Church. ${ }^{29}$ Cusanus reflected this distinction, without making specific mention of baptism. As far as possible, it was necessary for "perfect faith in Christ" to be "most pure, maximum, and formed by love." Faith could not be maximum unless it passed into the realm of action. The truth of the faith required an active response. Otherwise it was dead and, in Cusanus's words, "is not faith at all." Faith made the believer more like Christ, leaving the desires of the flesh for those of the spirit, the visible for the invisible, the mundane for the divine. ${ }^{30}$

In chapter 12 , Cusanus set forth his understanding of the Church to round out the book. It is worth noting that the institutional apparatus of the Church, so prominent in Cusanus's conciliarist writings, went without mention. Nonetheless, the fundamental idea of building up the Church was presupposed in this chapter. In De docta ignorantia, Cusanus spoke of humans as pilgrims, imitating Jesus, who had obtained, as no one else could, "unqualified maximum faith and unqualified maximum love." 31 Christ became the exemplar to which every Christian was expected to conform to be able to enter into the Church Triumphant. They could seek union with Christ without either attaining it perfectly, because of human limitations, or losing "their respective degrees on account of the union." 32 Resorting to Pauline terminology, Cusanus spoke of membership in one body through faith. In Johannine terms, he spoke of believers as branches of the one vine. The result, in Nicholas's words, was that, "Christ's humanity will be in all men, and Christ's one spirit will be in all

28. On Learned Ignorance, p. 151.

29. On Learned Ignorance, pp. 151-152. On Torquemada's doctrine of the Church, see Izbicki, Protector of the Faith: Cardinal Johannes de Turrecremata and the Defense of the Institutional Church (Washington, D.C.: Catholic University of America Press, 1981), pp. 31-41.

30. On Learned Ignorance, p. 152. Cusanus preached a similar message in his 1440 sermon on the text "Dies sanctificatus"; see his Opera omnia 16/4:333-57, no. 22. Compare this with his earlier, more Anselmian preaching on the Incarnation, e.g., his sermon on In principio erat verbum in Opera omnia 16/1:1-19, no. 1.

31. On Learned Ignorance, p. 153.

32. On Learned Ignorance, p. 154. 
spirits." 33 Although the achievement of union was described in terms of hunger and thirst, Cusanus made it clear that he was speaking of the intellect, which could not achieve its true food and drink, the Maximum, the Divinity, in this life, even as a member of the Church Militant. ${ }^{34}$ Only in the Church Triumphant would the human intellect share, as far as possible, in the hypostatic union by which "the true man Christ Jesus is united, in supreme union, with the Son of God." 35

In Cusanus's eyes, Church meant "a oneness of many [members], each seeking union without the loss of its identity and achieving that union in the maximal Church, the eternal now of the Church Triumphant." This union was achieved as the "maximum union" of all natures without distinction of greater or lesser in "the maximum union of the natures of Christ," which gives unity to the Church. ${ }^{36}$ Through Christ, the Church shared the "Absolute Union," the Holy Spirit, which unites the Father and the Son in living love. Here Cusanus affirmed not only the highest bond of ecclesial union but the Western doctrine of the Double Procession of the Holy Spirit, which had been harmonized, however briefly, with Eastern theology in the decree of union between the Greek and Latin churches promulgated at the Council of Florence less than a year before De docta ignorantia was completed. 37

In Cusanus's doctrine of the Church, as set forth in De docta ignorantia, the metaphysics, epistemology, and psychology of mystical union leave behind, for the moment, the vexing problems of pope, council, and princely politics. The True Church lies in the hereafter in the realization of faith in love in the Church Triumphant.

This doctrine of the Church might seem too esoteric to confront those same problems, but Cusanus saw it as the clue to the right ordering of the ecclesiastical institution. It allowed him to reject the declaration of the assembly at Basel, issued in 1439, the year which saw the Greek and Latin Churches declare themselves reunited, that

33. On Learned Ignorance, p. 154.

34. On Learned Ignorance, pp. 155-156.

35. On Learned Ignorance, p. 156.

36. On Learned Ignorance, pp. 156-157.

37. On Learned Ignorance, p. 157. See also Joseph Gill, The Council of Florence (Cambridge: Cambridge University Press, 1959), pp. 227-269, 412-415. 
conciliar supremacy is a dogma. On the basis of that dogma, the assembly had deposed Eugenius IV and elected Amadeus VIII of Savoy to reign as Felix V. ${ }^{38}$ It also permitted Cusanus, at least in his private writings, to avoid the excessively institutional emphasis of Eugenius and the apologist resident at his court. Eugenius had responded to Basel's attempt to depose him by issuing the decree Moyses, which condemned Basel as a congerie of rebels against hierarchical authority, like Dathan, Abiram, and Korah, the opponents of Moses. ${ }^{39}$ Eugenius also staged a debate between Cardinal Giuliano Cesarini, defending conciliarism, and the Dominican theologian Juan de Torquemada, defending papalism, as a prelude to a renewed diplomatic effort to win the princes to the papal cause. ${ }^{40}$ In that diplomatic struggle, as has been noted above, Eugenius and Basel competed to win over the princes through argument, persuasion, and outright bribes. ${ }^{41}$ In this context, Cusanus tried to apply the doctrine of learned ignorance to practical problems in quest of a solution which was theologically sound, spiritually oriented, papalist, and yet oriented to building up the Church.

As has been noted above, the occasion of this effort, made in the letter to Rodrigo Sánchez de Arévalo, was the Diet of Frankfurt (1442), the most recent of a series of meetings, involving the electors and other powers, lay and clerical, which sought to coordinate the Empire's response to the Conciliar Crisis. Arguments supporting conciliarism, papalism, and neutrality were heard; but, as had become typical of these gatherings, no final decisions were made. The diet was preceded by informal meetings from June 8 to July 7, which were interrupted by the coronation at Aachen of Frederick III, another Hapsburg prince, as King of the Romans. Formal proceedings occurred between July 7 and August 18. The combination of meeting and

38. Aeneas Sylvius Piccolominus (Pius II), De gestis concilii Basiliensis, ed. D. Hay and W. K. Smith (Oxford: Clarendon Press, 1967).

39. Unity, Heresy and Reform, 1378-1460, ed. C. M. D. Crowder (New York: St. Martin's Press, 1977), pp. 172-177.

40. Juan de Torquemada, Oratio synodalis de primatu, ed. Emmanuel Candal (Rome: Pontificium Institutum Orientalium Studiorum, 1954), and the translation by Izbicki, A Disputation on the Authority of Pope and Council.

41. Antony Black, Monarchy and Community: Political Ideas in the Later Conciliar Controversy (Cambridge: Cambridge University Press, 1970), pp. 86-129. 
coronation caused both Eugenius and Basel to choose their delegations carefully. The Eugenian delegation was led by the Castilian canonist Juan Carvajal and by Nicholas of Cusa. Basel's delegation was led by Louis d'Aleman, president of the council, the canonist Panormitanus and the theologian John of Segovia. Panormitanus and Cusanus presented the cases of their respective parties in almost purely institutional terms, including Nicholas's papalist version of the idea of consent, while John of Segovia and Cusanus argued in writing about the proper interpretation of Etsi non dubitemus, Eugenius's latest official statement of his claims. ${ }^{42}$ Instead of taking sides, Frederick took the occasion to advance his own plan for reunion, the latest plea that a council be gathered which would absorb the rival assemblies of the two parties. Neither party found this idea palatable, since it implied both the continued validity of the council sitting at Basel and the invalidity of its deposition of Eugenius IV. .3

These were the public events, both oral and written, of the Diet of Frankfurt. In comparison, Cusanus's letter to Arévalo is a breath of theological fresh air, placing institutional concerns in a cosmic context. It may not have pleased the recipient, who neither arrived in Frankfurt nor reacted to the letter publicly. As a canonist, one adhering to a thoroughly monarchic view of the Church, he may have found Cusanus's ideas peculiar, or at least irrelevant. Despite the presence of the letter in the Paris edition of Cusanus's works, the manuscript tradition is exiguous, suggesting private distribution of the text and a minimal reading public. ${ }^{44}$ The letter has been taken

42. For the written version of Panormitanus's speech Quoniam veritas, see Deutsche Reichtstagsakten 16, ed. Hermann Herre and L. Quidde (Stuttgart, 1928; rptd. Gottingen: Vandenhoeck \& Ruprecht, 1957), pp. 439-538, no. 212. For the written version of Cusanus's reply to that speech, see Acta Cusana 1/2:376-421, no. 520. On their doctrines, see Arnulf Vagedes, Das Konzil über dem Papst? (Paderborn: Schöningh, 1981); Heinz Hürten, "Die Konstanzer Dekrete Haec sancta und Frequens in ihrer Bedeutung fur Ekklesiologie und Kirchenpolitik des Nikolaus von Kues," in Das Konzil von Konstanz, ed. August Franzen and Wolfgang Müller (Freiburg i. B.: Herder, 1964), pp. 381-396. On Etsi non dubitemus and its role in these debates, see Remigius Bäumer, "Die Stellungnahme Eugens IV zum Konstanzer Superioritätsdekret in der Bulle Etsi non dubitemus," in Das Konzil von Konstanz, pp. 337-356.

43. Stieber, Pope Eugenius IV, pp. 94, 123.

44. Acta Cusana 1/2:372-73, no. 516; F. Nägel, "Die Schlettstader Handschrift 340 und ihre Bedeutung fur die Uberlieferungsgeschichte des Nicolaus Cusanus am 
as a defense of absolutism or, at least, as setting only vague limits on any possible abuse of papal power. ${ }^{45} \mathrm{~A}$ closer reading finds Cusanus straining against the limits of institutional theory, even as he defends the papacy.

At the very beginning of the letter to Arévalo, Cusanus made a leap from the question of pope or council more perfectly representing the Church to more speculative matters. His topic was the Word of God "through which all things came to be." Creation participated "in an unfolded, varied way in the unity of the eternal Word." Cusanus maintained, as in De docta ignorantia, the imparticipable nature of the Word, despite the dependance of creation upon It. In Christ, grace is "added over and above nature," opening the way to God through the hypostatic union. As in his previous discussion of the Church Triumphant, Nicholas dwelt on Jesus as "the enfolding of all the blessed," satisfying the intellectual need that nothing created can satisfy. The saved "participate variously" in Christ, making Him head of the Church, holding its "principate."

The Church Militant, "acknowledging the truth through faith and awaiting in hope the happiness which comes through charity" seeks to pass over to the Church Triumphant. The Church Militant has no knowledge of a believer's state of soul. Thus each believer participates in Christ according to individuality of natures; each, unable to grasp knowledge of God directly participates in truth through "enigma and mirror image" in hope of attaining the Truth at last. For Cusanus, the Church is the mystical body of Christ, because in it "the grace of Jesus Christ is unfolded" to all those adhering to Him in the Spirit. Since the Spirit "remains concealed in this sensible world," this is the "concealed Church," which "cannot be known in its sensible particularity of members." Reason can grasp generally who believes and lives in love. Conjectural knowledge of Christ's Church can be gained "through sensible signs." According to the "limited

Oberrheim," Mitteilungen und Forschungsbeiträge der Cusanus-Gesellschaft 6 (1967): $155-166$.

45. These differing emphases can be found in Sigmund, Nicholas of Cusa and Medieval Political Thought, pp. 266-272, 280; Erich Meuthen, Nikolaus von Kues, 1401-1464: Skizze einer Biographie (Munster: Aschendorff, 1964), pp. 77-78; Trame, Rodrigo Sánchez de Arévalo, p. 57, citing Hubert Jedin; Watanabe, Political Ideas of Nicholas of Cusa, pp. 106-108. 
understanding of this world," what can be perceived from these signs is the True Church, though the discernible Church "contains both those adhering to Christ in the Spirit and [those who do] not," though they acknowledge Christ. This "Church has sacred signs," "so that we may know through them those who are Christ's in the way in which conjectural knowledge can be obtained from signs."

This opinion on the concealed Church was not entirely new in Cusanus's writings. The opening chapters of De concordantia catholica had noted human inability to discern who were the true members of the Church, those united to Christ, the Word Incarnate; but that theological point was obscured by the great mass of the work, which focused on the institutional aspects of Christendom, both the reform of the ecclesiastical apparatus and the amelioration of conditions in the Empire. ${ }^{46}$ More in his speculative vein, Cusanus, just before writing the letter to Arévalo, had offered Cardinal Cesarini, in De coniecturis, his speculations on human diversity, pointing to the existence of one ultimate religion perceived by the human mind, itself the image of God, in a variety of manners. ${ }^{47}$ Although this speculation can be read as presaging the more irenic statements in De pace fidei, they also indicate the wellsprings of the unusual form of papalism found in the letter to Arévalo. Because the human mind was like unto God, man was most perfect when most like the divine exemplar. Thus the text of the letter emphasized Christ as the exemplar to which all members of the true, invisible Church must conform, however imperfectly. Even the pope, as we will see below, was obliged to conform to an exemplar, Peter, whose regime had been sanctioned by Christ for the work of building up the Church. Cusanus offered here, through his own version of the distinction between the Church Militant, known here and now through signs, and the Church

46. Nicholas of Cusa, Opera omnia 14, 2nd ed. (Hamburg: Meiner, 1963), pp. 33-36, 42-52. This passage was noted, but only to compare Cusanus's ideas with those of Gerard Groote, by Albert Hyma, The Christian Renaissance: A History of the Devotio Moderna, 2d ed. (New York: Century, 1925; rptd. Hamden, Conn.: Archon Books, 1965), pp. 262-263. For the limits of the Church's knowledge see Clyde L. Miller, "Perception, Conjecture and Dialectic in Nicholas of Cusa," American Catholic Philosophical Quarterly 64 (1990): 35-54.

47. In Nicholas of Cusa, Opera omnia 3 (Hamburg: Meiner, 1972), pp. 138-152. See also Watts, Nicolaus Cusanus, pp. 87-116. The De coniecturis is assigned to late 1441 or early 1442 in Acta Cusana 1/2:370, no. 507. 
Triumphant, to be known hereafter, a larger vision than the present crisis demanded, one which addressed the ultimate concern of his age about the nature of the True Church.

Medieval ecclesiastics regarded the Church as possessing four marks, signs which distinguished it from the gatherings of heretics. These were unity, holiness, catholicity, and apostolicity. Of them, holiness, once it became ascribed to the visible Church, was the most controversial. Both good and bad persons obviously were present among the baptized. ${ }^{48}$ Cusanus, who was well aware of Basel's negotiations with the Hussites, ${ }^{49}$ addressed this issue. He argued that the Church was holy by inference from its sacred signs, despite the presence of "evil and hypocritical men." Those who did not manifest these signs inwardly were excluded, since Christ "admits only the good to union." Since the mind could not know God directly, only through the inward divine image, the True Church of those united to the divine could not be known directly either, only located through signs.

Having set forth these larger premises, Cusanus went on in the letter to Arévalo to discuss the visible order of the "sensible Church," including the papacy. This order was given by Christ according to the "best manner in which it can be." This contention differed little from the papalist contention, advanced by Torquemada in his tracts, that monarchy was Aristotle's most perfect polity and so had been Christ's chosen design for His Church's governance. ${ }^{50}$ This portion of the letter to Arévalo is the best known. The Church, Cusanus said, was "unfolded" in Peter, the first to acknowledge Jesus as the Christ. On that profession, and on the one who professed it, the Church was founded. What was enfolded in Peter was unfolded in the Church, producing "one Church participating in the same confession in a varied diversity of believers." The Church needed to be both diverse and one, sharing "one entire confession in all and each part of it." As Adam was unfolded in humanity, Peter, the head of the visible Church, was unfolded in its members, in

48. Izbicki, Protector of the Faith, p. 37; Scott H. Hendrix, "In Quest of the vera ecclesia: The Crises of Late Medieval Ecclesiology," Viator 7 (1976): 347-378, at pp. 348-353, 356, 371-374.

49. E. F. Jacob, "The Bohemians at the Council of Basel," in Prague Essays, ed. R. W. Seton-Watson (Oxford: Clarendon Press, 1949), pp. 81-123.

50. Izbicki, Protector of the Faith, p. 83. 
a "variety of powers, orders and prelacies in the unity of faith in the Church." That entire unfolding of Peter (explicatio Petri) depended on God; but, within that limit, the supreme power "contains in its plenitude every power of all others." In the language of papalism, as represented by Torquemada, Peter had the plenitude of power; the lesser prelates, a share in the responsibility for ecclesiastical œgovernment. 51

The "most absolute divine power" conferred this power on Peter; the papal principate, in a more limited sense, was absolute, "set above the people over which it rules." In the language of Roman law, the pope was the prince "not bound by the laws" and "cannot be judged by his subjects." 52 Basel, unnamed in this passage, had committed the crime of rebellion by breaking away from "obedience and unity" when it tried to judge a "sacred prince." In terms derived from Boniface VIII's decree Unam sanctam, ${ }^{53}$ Cusanus argued that all spiritual and temporal powers were obliged to obey the pope. In case of doubt, the sacred prince must be presumed to be right, that his power was used correctly; and his command must be obeyed. Lesser prelates shared in Peter's powers, but less perfectly. Without saying so, Cusanus here answered the question about pope or council representing the Church more perfectly, since the lesser prelates had nothing which Peter did not possess more perfectly. As Christ was the exemplar of the invisible Church, the vera ecclesia, Peter was the exemplar of the visible Church, to whom all its members, including pope and prelates, had to conform. The pope especially was bound to imitate Peter, being most like him when engaged in building up the Church. The more closely the pope conformed himself to Peter, who had been empowered by Christ to be the enfolding

51. Gerd Heinz-Mohr, Unitas christiana: Studien zur Gesellschaftsidee des Nikolaus von Kues (Trier: Paulinus, 1958), pp. 95-105. This discussion of Peter's role may be understood as a reference to the Primitive Church: see Giuseppe Alberigo, "Forma ecclesiae nell'umanesimo cristiano, sopratutto secondo Nicolò da Cusa," Chiesa per il mondo: Miscellanea teologico-pastorale (Bologna, 1974) 1:351-375, at pp. 356-357. On Torquemada, see Izbicki, Protector of the Faith, pp. 59-60.

52. Digest 1.3.31.

53. Corpus Iuris Canonici Extrav. commun. 1.8.1, ed. E. Friedberg (Leipzig: Tauchnitz, 1879; rptd. Graz: Akademische Druck-Universität Verlagsamstalt, 1959) 2:124546. Cusanus made particular use of Unam sanctam in the memoranda against neutrality cited in note 11 above. 
of all prelacy, the more heinous any unjustified dissent from his rule became. ${ }^{54}$

All of these ideas argued for obedience to Peter, to his successors, to his present successor, Eugenius IV. Cusanus warned, however, that "a prelate may not abuse the power granted for the building up of the Church for the destruction of a subject church." Likewise, Cusanus wrote, "Peter's universal successor has no power over any particular successor of Peter through which the particular power of building up [the Church in dealing with] those subject to him suffers any change or is impeded." No pope had any power except from Peter. Having been raised in Peter's faith, he was obliged to the common good, building up that faith. The pope had no "free power of casting off, even once, the power enfolded through Peter healthily ordained for the rule of the Church, as long as it requires help in the building up [of the Church]." If the pope "receded from the unity of the Church," by pertinaciously exceeding his office and powers, the Church might recede from him. He had shown "himself unworthy of the sacred principate which he diminishes through abuse." Here it is worth noting that Cusanus emphasized the right order of the Church, the status ecclesiae, rather than heresy, in setting limits on the "absolute power" of the sacred prince. ${ }^{55}$ It also is worth noting that the pope is not described as reflecting automatically the perfection of his exemplar, Peter. Rather, his conduct was expected to be directed

54. This conformity, which was to bring the Church Militant home to the Church Triumphant, is emphasized by Alberigo, "Forma ecclesiae," pp. 358, 369-371. According to Alberigo, Peter becomes parallel to Christ, especially as an exemplar for the pope, in Cusanus's preaching; see p. 372, esp. note 84. An excerpt from a sermon on Peter appears in the Libri excitationum in Nicolai Cusae cardinalis opera (Paris, 1514; rptd. Frankfurt a.M.: Minerva, 1962), vol. 2, fol. 72r. A text of Sermon 284, Beatus es Simon bar lona, which emphasizes Peter's faith, his power enfolding all the faithful, and the need to follow him, was kindly provided to the author by Heinrich Paulli.

55. Heinz-Mohr, Unitas christiana, pp. 79-84. The term "status ecclesiae" had several possible meanings; see Yves Congar, "Status ecclesiae," Studia Gratiana 15 (1972): 1-31; Gaines Post, Studies in Medieval Legal Thought: Public Law and the State, 1100-1322 (Princeton: Princeton University Press, 1964), esp. pp. 241-414. The rendering here, "right order of the Church," fits the use of the term by the papalists, who regarded this concept as a limit on papal power only in the most dire emergencies. See Torquemada, A Disputation on the Authority of Pope and Council, pp. $x v, 50,56-57$. 
toward conforming more fully to the image of Peter, especially through actions which built up the Church. Only if the pope departed from his exemplar, obscuring the Petrine image, could his power be resisted. Such instances were expected to be uncommon, not frequent excuses to turn on the reigning pope. Nonetheless, here we see that Cusanus brought to the problems of a divided Church his awareness that even his own party, the Eugenians, ultimately fell short of realizing the vera ecclesia here on Earth, just as no human could realize fully the image of the incarnate Word. 56

Despite these limits, Cusanus returned to his emphasis on the pope's building up the Church through obedient prelates. Nicholas pointed to the efforts made at the Council of Ferrara-Florence to build up the Church. For that purpose the Council of Basel had been translated to Italy. The remnant of that assembly had attempted to "impose on the sacred prince a horrid abomination," deposition. Its members had succeeded only in "cutting off themselves most pertinaciously from him and from the universal catholic Church throughout the world." Cusanus concluded by speaking of affairs in Germany, urging Arévalo to use his visit to Frankfurt to uphold Frederick III's intentions, wrongly understood by the author at that time to be an effort to bring the Empire into the Eugenian camp.

The letter to Arévalo, as was noted above, can be understood as absolutist or as qualifying papal sovereignty with a teleological imperative to build up the Church. The latter view ties in quite naturally with Cusanus's churchmanship. Even his reply to Panormitanus at the 1442 Diet of Frankfurt, a papalist polemic, still emphasized the pope's role in building up the Church. ${ }^{57}$ Later the same emphasis

56. Augustine's idea of Peter having received the power of the keys as the Church's representative was known to Cusanus from Gratian's Decretum; see Corpus Iuris Canonici 24.1.6 (Friedberg 1:968), which is excerpted from Augustine's fiftieth tract on John. See also Giuseppe Alberigo, La chiesa nella storia (Brescia: Paideia, 1988), pp. 119-128, which emphasizes De concordantia catholica. On the conciliarist use of this passage, as well as of the more specifically Neoplatonic idea of Peter having received the keys in figura ecclesiae, often cited by the Decretists, see Brian Tierney, Foundations of the Conciliar Theory (Cambridge: Cambridge University Press, 1955), pp. 34-36. For a papalist refutation of the holistic interpretation of this text used by the conciliarists, see Izbicki, Protector of the Faith, pp. 31-51.

57. Acta Cusana 1/2:376-421, no. 520, at pp. 406-407 and 416. This work also made sporadic use of terms derived from the letter to Arévalo, describing all power as "contracted" in Peter and his successors (399) and all power "explicated" in the 
would appear in Cusanus's bitter public dispute with Pius II over the promotion of Jean Joffroy to the cardinalate, in which the German expressed his feeling of isolation in the curia, and in his Reformatio generalis, which stressed consultation in the exercise of ecclesiastical government and did so in the light of the mission of the hierarchy, in imitation of Christ, to build up the Church. ${ }^{58}$ Cusanus even made efforts to bring this vision into practice, especially when, as papal legate to the Empire in 1451-1452, he tried to curb practices he thought led the faithful away from the true center of Christianity, devotion to Christ, toward superstition. ${ }^{59}$ This effort was impeded by political and social realities beyond Nicholas's control; but the reforming impetus remained, even when Cusanus's efforts in the diocese of Brixen were undermined by their author's legalism and rigidity. 60

The Christocentric vision of the Church in the letter to Arévalo remained dear to Cusanus's heart through all of these adversities, a connecting thread in a career too often seen as discontinuous. This becomes apparent when the entire letter is read, looking back from its passages on explicatio Petri to the opening passages on the Incarnation and the conjectural Church. Those passages, in turn, must be read in the light of De docta ignorantia, particularly of its closing chapters. Without them, the idea of an inferential or conjectural Church seems a pallid sequel to Cusanus's conciliarist writings. ${ }^{61}$ Taking those

Church as being in Peter and his successors complicatorie at the beginning (402-403). Cusanus also argued that the supporters of Basel thought of the Church geometrically, as located in one city, rather than mathematically and abstractly reduced to one, Peter, and thus unstained by human failings $(406,412)$.

58. Pius II, Memoirs of a Renaissance Pope, tr. Florence A. Gragg, ed. Leona C. Gabel (New York: Putnam, 1959), pp. 227-230; Stephan Ehses, "Der Reformentwurf des Kardinals Nikolaus Cusanus," Historisches Jahrbuch 32 (1911): 281-297; Rudolf Haubst, Studien zur Nikolaus von Kues (Munster: Aschendorff, 1959), pp. 10-11. The same theme of imitatio Christi appears in Cusanus's sermons from this time, especially those from his visitation of Rome's major basilicas on the pope's behalf. See John W. O'Malley, Praise and Blame in Renaissance Rome (Durham, N.C.: Duke University Press, 1979), pp. 96-101.

59. See note 6 above.

60. See note 6 above and Pardon Tillinghast, "Nicholas of Cusa vs. Sigmund of Hapsburg: An Attempt at Post-Conciliar Church Reform," Church History 36 (1967): 371-390.

61. James E. Biechler, The Religious Language of Nicholas of Cusa (Missoula: Scholars Press, 1975), p. 169. According to Alberigo, Chiesa conciliare, pp. 291354, papalism ossified after rejecting Cusanus's fusion of hierarchy and consent. See 
chapters into account, Cusanus's understanding of the Church in the light of learned ignorance fits into its proper place.

In the light of learned ignorance there could be no certain knowledge of the True Church by the human intellect, in ultimate terms. The True Church contained those whose inward tie with Christ through faith and charity led them to God through the hypostatic union. The locus of the True Church could be discerned through sacred signs, but its true nature only could be known in the Church Triumphant. The visible institution, despite its admixture of good and bad members, remained, under the absolute power of God, the qualifiedly absolute power of the pope and the less perfect Petrine powers of other prelates, the best guide to the locus of the True Church.

Cusanus's idea of the Church fits uneasily into the late medieval concern about the True Church (vera ecclesia); but it is grounded in the patristic source materials he, like his contemporaries, used in their debates on institutional structure. Cusanus returned to the Augustinian emphasis on the invisible Church of those united to Christ by charity, an emphasis that did not preclude affirmation of the visible institution with its rites and structures. Like his contemporaries, however, he retained the medieval version of Augustine's ecclesiology, which emphasized faith formed through charity. ${ }^{62}$ The emphasis upon faith, in this context, was one on the visible profession of defined truths. It was on this externalized understanding of faith that medieval writers, especially the canonists, had based their arguments about hierarchic exercise of the powers of orders and jurisdiction and their concept of Christendom, a society founded on the profession of Christian truth. ${ }^{63}$ Even the Pauline idea of the Church as the mystical body of Christ, once that term had been divorced from the eucharist, described as the true body, also took on

also Alberigo, "L'unità della chiesa nel servizio del papato," in Nostalgie di unità: Saggi di storia dell'ecumenismo (Genoa: Marietti, 1989), 53-71, at pp. 57-61.

62. Scott H. Hendrix, Ecclesia in via (Leiden: Brill, 1974). For the impact of Augustine's emphasis on charity upon later writers, especially in the idea of avoidance of scandal, see Heinz-Mohr, Unitas christiana.

63. Gerhard Ladner, "Concepts of ecclesia and Christianitas and their Relation to the Idea of Papal plenitudo potestatis from Gregory VII to Boniface VIII," Miscellanea Historiae Pontificiae 18 (1954): 49-77. 
an institutional meaning. ${ }^{64}$ Academic argument had been able to hypothesize a visible Church at variance with the truth, but theologians were as ill prepared to deal with the division of the Church Militant by the Great Western Schism as canonists were to face the possibility of really deposing a pope. The Schism and the subsequent conciliar crisis forced them to struggle on two fronts, attempting to reunite and reform the institution while defending its validity against new and threatening heresies. Thus the theories now called conciliarism attempted, through use of corporation theory, texts from Scripture, and ideas of the mystical body, to find a ground on which the Church could act, through a council representing it, to renew the institution, while papalists reasserted a role for the ecclesial body dependent on the pope and attacked the holist theories of their opponents. ${ }^{65}$ Both parties, however, united in rejecting the theologies of Wyclif, Hus, and their followers, who, on the basis of a different reading of inherited texts, emphasized the invisible Church of those predestined to be saved to the extent of questioning the validity of the visible institution and rejecting the sacraments administered by priests not known to be among the elect. ${ }^{66}$

Cusanus's ideas about the Church permitted him to find a theological justification for papalism within his doctrine of learned ignorance; but it permitted him to do so while affirming the primacy of the invisible Church in a manner close to Augustine's theology, which left room for the visible institution with its rites and structures, including a papacy obliged to act to build up the Church. The closest congruence of this ecclesiological construct, to which Cusanus adhered for the rest of his life, is not to his former conciliarism or to the papalism of Torquemada and other contemporaries, it is to Luther's doctrine of a Church hidden from men but whose location is known by certain signs. Luther's signs, though they include ministry, differ drastically, however, emphasizing the proclamation of the pure Gospel. There was no room for the papacy, since truth was not to be found in "the

64. Henri de Lubac, Corpus mysticum, 2d ed. (Paris: Aubier, 1949), pp. 13-19, $116-135$.

65. For conciliarist holism, often grounded in Neoplatonic ideas, see Antony Black, Council and Commune (London: Burns \& Oates, 1979). For the papalist attack on it, see Izbicki, Protector of the Faith.

66. Hendrix, "In Quest of the vera ecclesia," pp. 371-374. 
synagogue of the papists and the Thomists." 67 This congruence may be explained by a common use of common sources or a common effort to merge the mystical elements of the late medieval heritage with nominalism. ${ }^{68}$ It also represents a common desire to reach beyond the limits of the Church in the present day to eternal verities. Cusanus's desire to find the concealed Church, even while serving the papacy, may be an intellectual measure of his frustration with his situation, at odds with his fellow Germans and yet not fully at home in the curia, just as his speculative thought represents a discontent with the limits of human reason in grasping eternal truth.

The Johns Hopkins University

\section{APPENDIX: NICHOLAS OF CUSA'S LETTER TO RODRIGO SÁNCHEZ DE ARÉVALO}

This translation is based on a partial one kindly provided by H. Lawrence Bond, Appalachian State University. The Latin text can be found in De auctoritate presidendi, ed. G. Kallen, Cusanus-Texte 2: Traktate 1 (Heidelberg, Carl Winter, 1935), pp. 106-112, which reprints the version found in vol. 2 of the Paris, 1514 edition as Epistle 1.

Most learned man, much venerated by me, lord Rodrigo [Sánchez] de Arévalo, archdeacon of Treviño, [I am writing to you] in order that, in these disturbances in the Church, in which you see the thoughts of many learned men being tossed from side to side by the opinion of the vulgar, you may be able to hunt down a final and truer conjecture according to the rules of learned ignorance. Observe that (although the subject of inquiry is about the pope and a council representing the Church), since all things are in the Word of God, through which

67. Paul D. L. Avis, The Church in the Theology of the Reformers (Atlanta: John Knox Press, 1981), pp. 13-24, esp. p. 19.

68. F. Edward Cranz, "Cusanus, Luther and the Mystical Tradition," in The Pursuit of Holiness in Late Medieval and Renaissance Religion, ed. Charles Trinkaus and Heiko Oberman (Leiden: Brill, 1974), pp. 93-102. 
all things came to be, that Word then enfolds all things and through It all things are unfolded in a diversity of difference participating in the Word Itself. All created things participate in an unfolded, varied way in the unity of the eternal ${ }^{1}$ Word, which enfolds all things, so that the Word Itself, although it is imparticipable, is participated in by the variety of a multitude of participants in that best way possible. All things, therefore, only exist in so far as they participate in the existence of the Word. The existence of every creature, therefore, flows from that absolute existence in the most immediate manner, since it is present equally in all things; but the diversity of creatures arises from the diversity of all things participating.

Proceeding to the next step, by affirming the grace which is added over and above nature, they are related thus to Christ, for, in rational human nature, every rational creature hypostatically united to divinity by grace in Christ Jesus can attain the grace of elevation to union with God, which is the ultimate happiness. Consequently, the blessed Jesus is the enfolding of all those made blessed. All rational creatures, therefore, can achieve the ultimate happiness in no other way than through participation in the grace of Jesus. In all those participating in that grace, therefore, the grace of Jesus is unfolded in a variety of participants. In this way the grace of Jesus is everything which is in all who are pleasing to God; and all those pleasing to God are, in Jesus, everything that is pleasing to God. The grace of Jesus, therefore, is one thing in which all the saved participate variously. Thus Peter, the greatest of all theologians, wishing to teach us, (as Luke says in Acts) ${ }^{2}$ referring to the ancient fathers, said [that] we believe he was made well in some manner through the grace of our lord Jesus Christ. This is the gospel's clear meaning and Saint Paul's doctrine, since Christ is the one holding the principate in all things and the head of the whole Church.

There are rational men, however, wayfarers in hope of salvation, to whom the truth of this grace was revealed through the incarnation of Christ; and [there are] some, acknowledging the truth through faith and awaiting in hope the happiness which comes through charity, who make up the Church Militant, which has through the grace

1. The text reprinted by Kallen wrongly has "alterni" at p. 106 .

2. Compare Acts 4:10. 
of Jesus Christ all things which are necessary for this, that, after the struggle, it may pass over to the Church Triumphant and attain to blessedness in Jesus Christ. This is the Church in which the grace of Jesus is unfolded according to the participatory nature of this world, because, although corruptible man, on account of the condition of his nature, cannot understand the truth without enigma and mirror image, at least he touches it through enigma and mirror image, or faith.

This requires the unique grace of Jesus Christ, by means of which the faithful, those laying hold [of truth] through faith, are wayfarers in hope of participating in unifying love in their own way and in a varied diversity. Wherefore, we call this Church mystically the body of Christ, because nothing but the grace of Jesus Christ is unfolded. Since, however, this is that one dove, the spotless bride, ${ }^{3}$ who has as high priest Jesus, who entered the heavens, ${ }^{4}$ whom she acknowledges, adhering to Christ in the Spirit, which remains concealed in this sensible world, then this concealed Church of Christendom cannot be known in its sensible particularity of members, who hold this confession and remain worthy of love, but only is grasped in a certain generality of reason through the power of reason. Just as the Church Triumphant, above reason, is accessible only in simplicity of understanding, so [the Church] Militant [is accessible only] in generality of reason. It is necessary, therefore, in the sensible world to try conjecturing about Christ's Church through sensible signs, since otherwise the truth of reason could not be grasped. For this reason that conjectural Church in this sensible world, according to the limited understanding of this world, is the True Church, although within this conjecture, received from signs, it contains both those adhering to Christ in the Spirit and [those who do] not. This Church of this sensible world is constituted of those who show by sensible signs that they participate in Christ, since they are those who acknowledge Christ, the son of God. For this reason this Church has sacred signs constituted so that we may know through them those who are Christ's in the way in which conjectural knowledge can be obtained from signs.

3. Compare Song of Songs 6:9 and Ephesians 5:27.

4. Compare Hebrews 9:11-14. 
I say, therefore, that this Church of Christ is regarded as holy, judged in this sort of conjectural way, even if evil and hypocritical men mingle themselves under these sacred signs, which signs are sacred as far as conjecture reaches. This Church, therefore, does not contain all who adhere to Christ. Those who have manifested no sensible sign inwardly remain excluded from this judgment; nor do all those in this Church adhere to Christ, who admits only the good to union. Since, however, the condition of this life is such that the Church has to be this way, we do not hesitate [to say] that it was ordered by Christ in the best manner in which it can be. Thus, just as the Church is perfect in its own way, in so far as it has a head; it is fitting for the sensible Church to have a sensible head; and, for this reason, the sensible head of this Church is the pontiff, who is chosen from among men. In him this Church exists in an enfolded manner as in the first confessor of Christ. We know that Peter was the first confessor of Christ among men; and for this reason, from his confession of the Rock who is Christ, Peter, receiving a name [from It], unfolded the Church enfolded in himself first of all through the word of doctrine. ${ }^{5}$ There is not, therefore, any other Church than the union of the faithful in the confession of Peter, which has its inception from Peter through supernal revelation. The unfolding of Peter, therefore, who is named after the Rock, and enfolding the Church, is one Church participating in the same confession in a varied diversity of believers. Since, however, the multitude can participate in unity only in a varied diversity, the Church cannot subsist, consequently, except in a varied participation in unity. For this reason it is necessary for there to be various members of the one body of the Church, in whom there is that one entire confession in all and in each part of it. The unity of the Church, therefore, exists in a varied diversity. Just as the strength of unity cannot be attained except in a diversity, so the strength of the enfolding origin can be grasped only in the unfolded things originated. The strength of the nature of Adam, the enfolding father, is not grasped otherwise than in the men unfolded from him; nor [the strength] of the Creator, except in those creatures. In the manner mentioned above, the enfolded strength of Peter, the head of the Church, cannot be grasped except in the Church unfolded from

5. Compare Matthew 16:18-19. 
him. Thus, when we behold the variety of powers, orders, and prelacies in the unity of faith in the Church, seeing in it the entire wellordered, decorous variety originally enfolded in Peter, we are moved to conjectures concerning the admirable power and strength of Peter; and we grasp the plenitude of all things possible in the Church for its preservation and the unique power of Peter for [its] direction. There is no unfoldable unity in the multitude unless the strength of unity exists in an unfolded way. We know this universal principate, originally enfolding every particular principate, [to be] inexhaustible through multiplication of particular [principates]. If, therefore, the powers of patriarchs, archbishops, metropolitans, bishops, and priests are in the Church, they have to be enfolded. The enfolding, however, does not originate with itself; rather it depends on the absolute. Wherefore, the power of the first and supreme one contains in its plenitude every power of all others. Thus there is no power except one, that of the first, which is shared variously in a diversity of prelates, by none, however, maximally. As such it is imparticipable.

You see now, most prudent father, how incorrect it is to say that the power of particular prelates can equal or surpass that of the universal prince. You see the divine dictum of Pope $\mathrm{Leo}^{6}$ how every power first receives its being from that most absolute divine power; but in the Church [this is received] through Peter, the head and prince of the Church. Note, therefore, how there is no absolute power of the prince, except that of the most high God. But every principate participates variously in the diversity of the contracted [power]. The principate in the Church, therefore, is absolute in its own way, since in it the Church is enfolded. Thus any principate participates in its own way in this absoluteness, when it is set above the people over which it rules. Wherefore, it is unreasonable to say that a prince in his kingdom, where he is prince, shares power equally or is subordinate. The principle of non-contradiction does not permit such a sharing [of power]. Some wise men, who said the prince is not bound by the laws and cannot be judged by his subjects, understood this. ${ }^{7}$ Therefore, it should be sufficiently clear to you what an execrable crime it is to break away from obedience and unity and how presumptuous [is] a

6. Corpus Iuris Canonici 19.7 (Friedberg 1:62).

7. Digest 1.3.31. 
judgment of subjects against the sacred prince, under whatever guise this might be attempted. You even see every sacred principate in the Church placed under the first, in so far as it is enfolded within it and not otherwise; for the sacred universal principate exists to build up the Church. Wherefore, every principate, spiritual or temporal, in so far as it serves this end, can be in the Church; and in so far as it resists this end, the principate is not in the Church, since it does not participate in the sole universal ecclesiastical power, which, in every power which is in the Church, is whatever that [power] is in a contracted way.

You see different powers, spiritual and temporal, unfolded clearly within the Church by coming together in the unity of the universal power. It is not difficult now for you to understand how every faithful person, whether king, or ruler or any other [power] must be subject to the sacred prince of the Church, insofar as they wish to be part of the Church which that universal power encompasses. And this [is true] when the prince of the Church, according to the strength of this principate, decides on commands. Where, however, the prince commands that things be done which they do not believe pertain to the end of building up the Church entrusted to him, the command does not proceed from the principate; wherefore, it is not necessary to obey it. If, however, there is a doubt and the prince's intention is not clear, it must be assumed of the sacred prince that [he has] used correctly the power entrusted [to him]; and [he] must be obeyed.

Although we understand, therefore, that in the Church, where there are good and bad people, the sacred prince can be good or evil, and we see that his power cannot oppose the Church. Since, in those things which are not enfolded in that power, no one is subject to him, there is no peril in obeying in doubtful matters; but great peril in not obeying. Augustine ${ }^{8}$ says here that no reason can be given why it is necessary to start a schism; wherefore, schism is a diabolical, inexcusable crime.

Note, father, how, since the primitive Church was unfolded variously from the universal, contracted, enfolded power of Peter according to various particular prelacies, any prelate participating in his particularity, in the contracted power of Peter, [has] the same power

8. Compare Corpus Iuris Canonici 23.4.19 (Friedberg 1:906). 
which Peter had, except for its contraction. Wherefore, because in this all who have care of the Lord's flock are Peter's successors, it is apparent to the wise that the universal power of the sacred prince of the Church cannot be above any particular [power] except according to the condition [of holding] the sacred principate, that is for the building up [of the Church]. Thus, in so far as he is Peter's universal successor, he could have no power over any particular successor of Peter through which the particular power of building up those subject to him suffers any change or is impeded. Otherwise, however, when the sacred universal prince acts to oversee, a prelate may not abuse the power granted for the building up of the Church for the destruction of a subject church.

From this I see murmurs arising, which easily could remove the universal sacred prince, alleging Peter's successor [to have originated] after the Church unfolded by Peter, not as if he were another Peter, called after the Rock on which the Church with its order had to be built, since to undermine order and state of the universal Church is not to follow Peter. Every Roman and chief pontiff, however, in the unfolded scheme and right order of the Church has no power except from Peter, since this unfolding was founded through the power of Peter for the building up of the Church, which already was formed through him, when a son born in the Church is raised up to the principate of Peter. Because those things which are found unfolded now in the Church by Peter's successors in the aforesaid way are those which originate from the power of the universal prince, it is not convenient for that same power, now existing unfoldedly in the elected pontiff to be infringed in some way. There are rules, an order of estates, and other universal things of this sort, except in the case in which the pontiff himself discerns either equity or useful change for the building up of the Church; in this case it has to be noted that, when he does not attempt to promote the common good, he offends and scandalizes [his] brothers.

In the same manner, those more wise always have understood that, although the hand of the sacred prince extended to build up the Church can be inhibited or impeded by no observance or rule of the fathers, even in councils, there is not in him, nevertheless, a free power of casting off, even once, the power enfolded through Peter healthily ordained for the rule of the Church, as long as it requires help in the building up [of the Church]. But it befits no see more to 
execute what was established inviolably by the holy fathers than [it befits] the true successor of Peter in those things which proceed in an unfolded manner from the same power of Peter.

You see now [that], when the sacred prince of the Church presumes [to do] anything against the statutes of the holy fathers, where he does not seem to be moved by reason of utility or necessity but rather from some particular, unworthy cause in such a manner [that] he then offends in it against the previous mandates of Peter himself, he exceeds the nature of his power. For which reason it would not be inconvenient, if he should persist in this pertinaciously, [that] the Church could recede from him; when he has receded from the unity of the Church, without which the Church cannot exist, this does not introduce schism. In this way the pontiff must be understood to be subject to the canons of the holy fathers, as if there were in him no power of abusing according to his desire things well ordered; and, if he should persist in this pertinaciously, then he would show himself unworthy of the sacred principate which he diminishes through abuse.

In some manner Peter lives in his universal successor; just so in the canons of the fathers those fathers [live], and the Church, in the fathers. Thus Peter is said to live in the Church in those rules of the holy fathers, as long as that [power] gives aid for that purpose of building up the Church. And thus it is, according to the intellectual rule of learned ignorance, [that] the Church is in the pontiff in an enfolded manner. And [the sacred prince] equally is in the Church, that is when it keeps watch over its holy ordinances in a fitting manner; these things, if they are extended to certainty, open the intellect, so that the most incorrect writings of some are spurned easily.

It should be seen how easily our holy lord cannot be prohibited by any ordinance of any synod, when the council for leading back of the eastern Church [is] in session, in that place which was more convenient for doing such things; and he ordained that he would dissolve all other assemblies for that purpose; and he dismissed the fathers from Basel, so that they could concur freely in that holy union. For, just as there is not power of the pontiff for the destruction of things done well by the fathers, so there is no power under heaven which can diminish his authority; rather he should bring back the erring to the fold. Those purblind men are seen to have been out of all sense in a spirit of fury when they claimed for themselves some sort of judicial power over the sacred prince; and the savages tried to impose 
on the sacred prince a horrid abomination, cutting off themselves most perniciously from him and from the universal catholic Church throughout the world. That is enough now, since what they did is well known to you.

Clearly you have the illuminated eye of intelligence so that you can see very well that their sophistic excuses are supported by no authority or reason. Their vain ambition and apostate rebellion are apparent to the whole world, into which those desperate men strive with great diligence and care to infuse a worse poison; and particularly, to the king of Castile and Leon, ${ }^{9}$ most serene and most worthy of highest praise, who shows through you the solicitude, so dear to God, of conserving unity in these far distant regions of the Germanies with such zeal, so that nothing at the diet may happen unfortunately to the king, [who is] most preoccupied with the daily pressures of the Saracens, ${ }^{10}$ lest such bitter foes of Christendom should be tolerated under some perilous subterfuge by those who seek, by a rash deed, to strike down with anathema the vicar of Christ. ${ }^{11}$ That most clement prince will carry back imperishable glory for his inward devotion. That man of most holy desires cannot be left unconsoled by God and the Church. For these his most holy vows cannot be turned away from heaven unaccepted because of your most circumspect actions in this illustrious diet of the unconquered king of the Romans ${ }^{12}$ and the most glorious electors of the sacred Roman Empire, since, rejoicing in the Lord over all things done well, you will return to narrate [them]. I wish most cordially that you will bring that about, the more so since you know I have labored for the same thing most fervently for many years.

Farewell.

9. Juan II.

10. Literally "Agarenorum."

11. Eugenius IV.

12. Frederick III. 